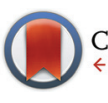

CrossMark $\leftarrow$ click for updates

Cite this: Dalton Trans., 2015, 44, 6023

Received 2nd January 2015, Accepted 5th February 2015

DOI: $10.1039 / c 5 d t 00008 d$

www.rsc.org/dalton

\section{An anionic phosphenium complex as an ambident nucleophile $\dagger$}

\author{
B. Stadelmann, ${ }^{a}$ J. Bender, ${ }^{a}$ D. Förster, ${ }^{a}$ W. Frey, ${ }^{b}$ M. Nieger ${ }^{c}$ and D. Gudat*a
}

A unique anionic phosphenium complex was prepared from reaction of an $\mathrm{N}$-heterocyclic chlorophosphine with Collman's reagent or $\mathrm{K}\left[\mathrm{HFe}(\mathrm{CO})_{4}\right] / \mathrm{NaH}$ and characterized by spectral and XRD data. The complex behaves as an ambident nucleophile. Reactions with acetic acid, $\mathrm{ClSnPh}_{3}$, and a further equivalent of an $\mathrm{N}$-heterocyclic chlorophosphine proceed via electrophilic functionalization at the metal site to yield appropriate mono- or bis-phosphenium complexes. Reaction with $\mathrm{Mel}$ at $-70{ }^{\circ} \mathrm{C}$ produces a P-alkylation product as the first spectroscopically detectable intermediate, which decays at a higher temperature to give a mixture of free $\mathrm{P}$-methylated $\mathrm{N}$-heterocyclic phosphine and its $\mathrm{Fe}(\mathrm{CO})_{4}$ complex. The different reaction products were characterized by spectral and XRD data. Computational studies indicate that the NHP units in all complexes display $\pi$-acceptor behaviour but show no disposition to adopt phosphide-like character or formally oxidize the metal centre.

\section{Introduction}

Cyclic diaminophosphenium ions (Ia, Scheme 1) are isosteric analogues of N-heterocyclic carbenes (NHCs, Ib) and, like NHCs, form a large variety of transition metal complexes. ${ }^{1}$ However, whereas NHCs are nucleophiles and act mainly as strong $\sigma$-donor ligands, $\mathrm{N}$-heterocyclic phosphenium ions (NHPs) are ambiphiles that combine a strong $(\pi$-)acceptor power with limited $(\sigma-)$ donor ability, and interact with electron poor metal fragments to form a main dative $\mathrm{M} \rightarrow \mathrm{L} \pi$-bond and a weaker dative $\mathrm{L} \rightarrow \mathrm{M} \sigma$-bond. ${ }^{1,2}$ This bonding situation compares to that in metal carbonyls or Fischer-type (electro-<smiles></smiles>

la $\left(E=P^{+}\right)$ lb $(E=C)$

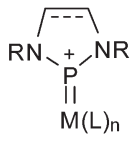

Ila

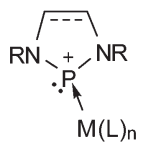

Ilb
Scheme 1 Generic molecular structures of NHCs (Ib), NHPs (la), and NHP complexes (Ila, b). The symbol $=--$ indicates that the heterocycle contains either a single or, alternatively, a double bond.

\footnotetext{
${ }^{a}$ Institut für Anorganische Chemie, Universität Stuttgart, Pfaffenwaldring 55 , 70550 Stuttgart, Germany. E-mail: gudat@iac.uni-stuttgart.de; Fax: +49 711685 64241; Tel: +49 71168564186

${ }^{b}$ Institut für Organische Chemie, Universität Stuttgart, Pfaffenwaldring 55, 70550 Stuttgart, Germany

${ }^{c}$ Laboratory of Inorganic Chemistry, Dept. of Chemistry, University of Helsinki, P.O. Box 55, o0014 University of Helsinki, Finland

$\dagger$ Electronic supplementary information (ESI) available: Representation of NMR data and computational results. CCDC 1032390-1032394. For ESI and crystallographic data in CIF or other electronic format see DOI: 10.1039/c5dt00008d
}

philic) carbene complexes, ${ }^{1 e, 2}$ and the M-P-bonds exhibit accordingly distinct double bond character ( $c f$. IIa, Scheme 1). In complexes with electron rich and weak Lewis acidic metal fragments, NHPs can also act as electrophiles ${ }^{3}$ ("Z-type ligands"4) that have been considered to bind essentially via a dative $\mathrm{M} \rightarrow \mathrm{P}$ bond $(c f$. IIb, Scheme 1$){ }^{5}$ It has recently been pointed out that the bonding in complexes of this type may be portrayed as the interaction of an anionic ("X-type") phosphido ligand with a formally oxidized metal centre, and that the dualism of both descriptions together with the pyramidalization at the phosphorus atom and M-P bond lengthening upon transition from IIa to IIb allows one to draw parallels to the "non-innocent" behaviour of metal nitrosyls. ${ }^{6}$

The unique disposition of NHPs to interact with low valent metal centres has repeatedly been used to stabilise anionic metal fragments $\left[\mathrm{M}(\mathrm{L})_{n} \mathrm{X}\right]^{-}$(containing usually a zero-valent metal atom and an anionic ligand $\mathrm{X}),{ }^{2 b, 3,7,8}$ so that to date both cationic ([(NHP)M(L) $\left.]^{+}\right)$and neutral NHP complexes $\left(\left[(\mathrm{NHP}) \mathrm{M}(\mathrm{L})_{n} \mathrm{X}\right]\right)$ are known. ${ }^{1-8}$ Although the chemistry of the latter has not been widely explored, they are expected to display a similar distributed nucleophilicity as neutral complexes of acyclic aminophosphenium ions which can be attacked by electrophiles at the metal atom, the phosphorus atom, or the MP bond, respectively. ${ }^{9}$

In the light of these findings, complexes $\left[(\mathrm{NHP}) \mathrm{M}(\mathrm{L})_{n}\right]^{-}$ with an overall negative charge and CC-unsaturated NHP ligands (1,3,2-diazaphospholenium ions) make an interesting synthetic target. These specimens should be accessible from suitable phosphorus electrophiles and metallate dianions featuring a metal atom in the negative formal oxidation state. Coordinated diazaphospholenium ions, apart from providing 
tunable steric protection, exhibit low tendency toward "noninnocent" behaviour, ${ }^{7 b}$ and should thus provide electronic stabilization without entirely removing the electron excess at the metal atom. The formed complexes might then still behave as metal-centred nucleophiles, a class of compounds that has lately gained attention for uses in catalysis. ${ }^{10}$

Following these lines, we report here on the synthesis of a NHP carbonyl ferrate, which is a first anion analogue of cationic and neutral phosphenium complexes, and on initial reactivity studies, which confirm that this species behaves in fact as a metal-centred nucleophile but retains also some ambident character.

\section{Results and discussion}

By analogy to the known synthesis of neutral phosphenium tricarbonylcobaltates, ${ }^{5}$ 2-chloro-1,3,2-diazaphospholene 1 reacted with Collman's reagent $\mathrm{Na}_{2}\left[\mathrm{Fe}(\mathrm{CO})_{4}\right]$ via salt elimination and decarbonylation to afford the anionic NHP complex [( $\left.\mathrm{NHP}^{\mathrm{Dipp}}\right)$ $\left.\mathrm{Fe}(\mathrm{CO})_{3}\right]^{-}\left(2 ; \mathrm{NHP}^{\mathrm{Dipp}}=\right.$ 1,3-di-(2,6-di-isopropylphenyl-1,3,2diazaphospholenium, Scheme 2).

A crude product of composition $\mathrm{Na}$ [2] was isolated as a brown-red, highly air and moisture sensitive solid after separation of $\mathrm{NaCl}$ and evaporation of the solvent. Crystalline $\left[\mathrm{PPh}_{4}\right][2]$ was isolated after anion exchange with $\left[\mathrm{PPh}_{4}\right] \mathrm{Cl}$. Both products were readily identified by spectral data and a singlecrystal XRD study of $\left[\mathrm{PPh}_{4}\right][2]$ (Fig. 1). The orthorhombic crystals (space group $\mathrm{Pna}_{1}$, no. 33) contain two crystallographically independent pairs of isolated $\mathrm{Ph}_{4} \mathrm{P}^{+}$and $\left[\left(\mathrm{NHP}^{\text {Dipp }}\right) \mathrm{Fe}-\right.$ $\left.(\mathrm{CO})_{3}\right]^{-}$ions with similar metric parameters. The distorted tetrahedral and trigonal planar (sum of bond angles $360.0(5)^{\circ}$ ) coordination at the iron and phosphorus atoms and the bond lengths in the planar NHP-rings of the anion (see Fig. 1) are similar as in the isosteric complexes $\left[\left(\mathrm{NHP}^{\mathrm{R}}\right) \mathrm{Co}(\mathrm{CO})_{3}\right]^{5}(\mathrm{R}=$ Mes, $t \mathrm{Bu})$. The Fe-P bonds (1.989(2) $\mathrm{A})$ are shorter than in iron complexes with diaminophosphenium (Fe-P 2.018(2)-2.15 $\AA^{11}$ ) or -phosphine ligands (Fe-P > $2.23 \AA{ }^{12} 6$ (vide infra): 2.212(1) $\mathrm{A}$ ), and $\mathrm{Fe}-\mathrm{C}$ distances $(1.750(6)-1.768(5) \AA)$ match those in tetra-

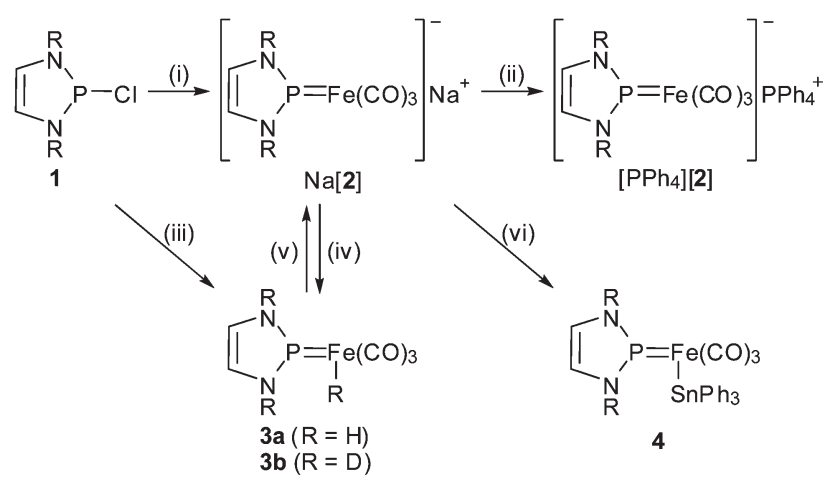

Scheme $2 \mathrm{R}$ = Dipp; conditions: (i) 1 equiv. $\mathrm{Na}_{2}\left[\mathrm{Fe}(\mathrm{CO})_{4}\right], \mathrm{THF},-78^{\circ} \mathrm{C}$, $2 \mathrm{~h}$; (ii) 1 equiv. $\mathrm{Ph}_{4} \mathrm{PCl}, \mathrm{THF}$; (iii) 1 equiv. $\mathrm{K}\left[\mathrm{HFe}(\mathrm{CO})_{4}\right],-78{ }^{\circ} \mathrm{C} \rightarrow$ r.t., $2 \mathrm{~h}$; (iv) $\mathrm{CH}_{3} \mathrm{CO}_{2} \mathrm{H} / \mathrm{CH}_{3} \mathrm{CO}_{2} \mathrm{D}$, r.t.; (v) 1 equiv. $\mathrm{NaH}, 0{ }^{\circ} \mathrm{C}, 12 \mathrm{~h}$; (vi) 1 equiv. $\mathrm{Ph}_{3} \mathrm{SnCl}$, r.t., $5 \mathrm{~min}$.
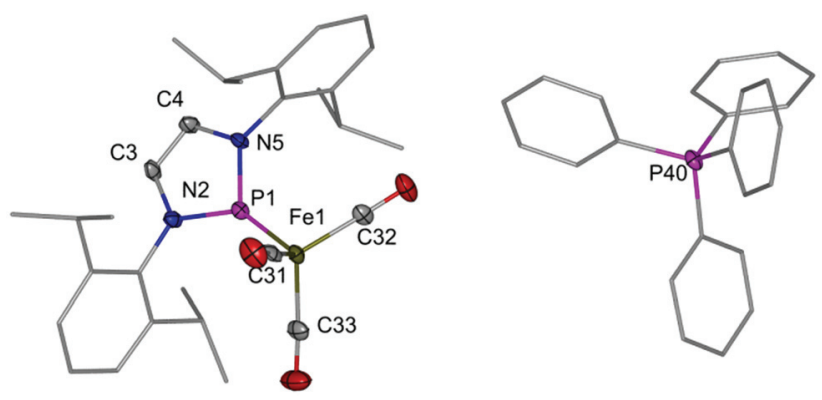

Fig. 1 Representation of the molecular structure of one crystallographically independent ion pair in $\left[\mathrm{PPh}_{4}\right][2]$. $\mathrm{H}$-atoms were omitted for clarity. Selected bond lengths $[\AA \AA]$ (numbers in brackets refer to the second crystallographically independent unit): Fe1-C31 1.762(5) [1.768(5)], Fe1-C32 1.768(5) [1.750(6)], Fe1-C33 1.758(6) [1.754(5)], Fe1$\mathrm{P} 1$ 1.989(1) [1.989(2)], P1-N5 1.689(4) [1.703(4)], P1-N2 1.712(4) [1.710(4)], N2-C3 1.380(6) [1.399(6)], C3-C4 1.337(6) [1.333(7)], C4-N5 $1.408(6)[1.416(6)]$.

carbonyl ferrates $\left(1.730(4)-1.762(5) \AA^{13}\right)$ and $\mathrm{Tl}\left[\mathrm{Fe}(\mathrm{CO})_{3} \mathrm{NO}\right]$ $\left(1.800(8) \AA^{14}\right)$. Noteworthily, spectroscopic features of 2 include a marked deshielding of the ${ }^{31} \mathrm{P}$ NMR signal (which is typical of most aminophosphenium complexes), ${ }^{1,6}$ and a large counter ion dependence of ${ }^{31} \mathrm{P}$ chemical shifts $\left(\delta^{31} \mathrm{P}=211.1\right.$ for $\mathrm{Na}[2] \nu s .197 .9$ for $\left.\left[\mathrm{PPh}_{4}\right][2]\right)$ and $\nu \mathrm{CO}$ normal modes $(\tilde{\nu}=$ $1912,1834,1767 \mathrm{~cm}^{-1}$ for $\mathrm{Na}[2]$ vs. $\tilde{\nu}=1894,1813,1798 \mathrm{~cm}^{-1}$ for $\left.\left[\mathrm{PPh}_{4}\right][2]\right)$ which reflects presumably differences in the ion pairing behaviour. ${ }^{15}$ The $\nu \mathrm{CO}$ frequencies in both species are lower than in anionic tricarbonyl iron complexes such as $\left[\left(\mathrm{Ge}_{8}\right) \mathrm{Fe}(\mathrm{CO})_{3}\right]^{3-}$ or $\left[\left(\mathrm{C}_{8} \mathrm{H}_{8}\right) \mathrm{Fe}(\mathrm{CO})_{3}\right]^{-}$where the negative charge seems mainly ligand centred, ${ }^{16}$ but do not come close to the values observed for gaseous or matrix isolated $\left[\mathrm{Fe}(\mathrm{CO})_{3}\right]^{-}$ $\left(\nu \mathrm{CO}=1780-1795 \mathrm{~cm}^{-1}\right.$ (ref. 17) $)$ and dianions like $\left[\mathrm{Fe}(\mathrm{CO})_{4}\right]^{2-}$ $\left(\nu \mathrm{CO}=1920,1830,1780,1730 \mathrm{~cm}^{-1}(\right.$ ref. 18$\left.)\right)$ or $\left[\mathrm{Fe}(\mathrm{CO})_{3}\left(\mathrm{PR}_{3}\right)\right]^{2-}$ $\left(\nu \mathrm{CO}=1817,1803,1710,1663 \mathrm{~cm}^{-1}\right.$ for $\mathrm{R}=$ OMe; 1789, 1692, $1637 \mathrm{~cm}^{-1}$ for $\mathrm{R}=\mathrm{Ph}^{19}$ ). Although the unavailability of exact force constants prohibits a quantitative comparison, these trends confirm, in line with the results of a previous study on cationic NHP complexes, ${ }^{7 a}$ the picture of the cationic NHP unit as a strong $\pi$-acidic ligand which outperforms neutral acceptors like CO or phosphites.

All in all, the structural and spectral features of 2 match those of Fischer-carbene analogue phosphenium complexes $^{2,5,7}$ and indicate that the NHP unit acts as an ambiphilic $\sigma$-donor/ $\pi$-acceptor rather than the pure Z-type ligand. In order to validate this hypothesis by DFT calculations (B3LYP/def2tzvp with inclusion of solvent effects using a polarizable continuum model; see Experimental for details), we performed a geometrical optimization and ensuing NBO calculation ${ }^{20}$ on the model anion $\left[\left(\mathrm{NHP}^{\mathrm{Me}}\right) \mathrm{Fe}(\mathrm{CO})_{3}\right]^{-}\left(2^{\prime}\right)$. The computed molecular structure replicates all important structural features of 2 , including in particular the planar coordination at phosphorus and short P-Fe bond length (2.006 $⿱$ ). Inspection of KS orbitals (see ESI $\dagger$ ) and Wiberg Bond Indexes (WBI) confirms that the $\mathrm{Fe}-\mathrm{P}$ bond receives a strong covalent contribution from a combination of dative $\sigma$ - and $\pi$-bonding interactions, and has thus 
notable double bond character (WBI 1.41 vs. 1.35 for the Fe-C bonds). The overall natural charge of the coordinated NHP unit $(+0.86)$ is lower than in the free ligand, indicating that the NHP plays a part in delocalizing the negative charge on the carbonyl ferrate moiety but retains its electrophilic character. The large opposite charges on the iron (-2.41) and phosphorus atoms (+1.52) suggest that the metal-ligand bond also has a strong electrostatic component. The population analyses indicate that, regardless of any superficial analogies, the behaviour of the NHP moiety in $2 / 2^{\prime}$ differs markedly from that of the strongly reduced nitrosyl unit ${ }^{21}$ in $\left[\mathrm{Fe}(\mathrm{CO})_{3}(\mathrm{NO})\right]^{-}$.

Considering that such a charge distribution should support a behaviour as an iron-centred nucleophile, we studied reactions of $\mathrm{Na}$ [2] with various electrophiles. Treatment with acetic acid gave iron hydrido complex 3a (Scheme 1) which was identified by the observation of mutually coupled $\left({ }^{2} J_{\mathrm{PH}}=\right.$ $88 \mathrm{~Hz})$ NMR signals for a metal bound $\mathrm{H}$-atom $\left(\delta^{1} \mathrm{H}=-8.88\right)$ and the phosphorus atom of a phosphenium ligand $\left(\delta^{31} \mathrm{P}=\right.$ 225.0). The reaction of $\mathrm{Na}[2]$ with deuterated acetic acid gave appropriately $\mathbf{3 b}$. Complex $\mathbf{3 a}$ is also directly accessible from $\mathbf{1}$ and $\mathrm{K}\left[\mathrm{HFe}(\mathrm{CO})_{4}\right]^{22}$ which reacts below ambient temperature under metathesis and decarbonylation (Scheme 2). This conversion contrasts known reactions of chlorophosphines, which proceed via transfer of the hydride to the phosphorus atom and yield phosphine complexes. ${ }^{23}$ A single-crystal XRD study revealed that the iron atom in $\mathbf{3 a}$ exhibits trigonal bipyramidal coordination and the $\mathrm{H}$ - and NHP-ligands occupy axial and equatorial positions, respectively (Fig. 2).

The protonation of 2 to $3 \mathbf{a}$ can be reversed by the action of a strong base $(\mathrm{NaH})$, and combining the reaction of $\mathrm{K}[\mathrm{HFe}-$ $\left.(\mathrm{CO})_{4}\right]$ and $\mathbf{1}$ with a subsequent deprotonation offers thus alternative access to anion 2. Monitoring the deprotonation of 3a by ${ }^{31} \mathrm{P}$ NMR allowed us to establish that the reaction is slow and 2 and 3a undergo no dynamic exchange on the NMR time scale, indicating that the kinetic acidity of $\mathbf{3 a}$ is unusually low.

Reaction of $\mathrm{Na}[2]$ with $\mathrm{ClSnPh}_{3}$, which is a softer electrophile than $\mathrm{H}^{+}$, proceeds likewise under attack at the metal to afford complex 4 (Scheme 2) which was identified by spectral

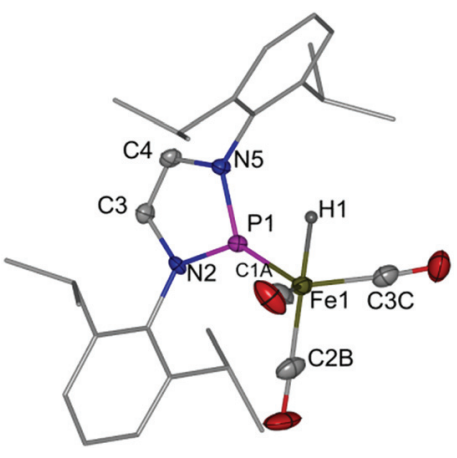

Fig. 2 Representation of the molecular structure of $3 a$ in the crystal. $\mathrm{H}$-atoms (with the exception of $\mathrm{H} 1$ ) were omitted for clarity. Selected bond lengths $[\AA]]$ : Fe1-C1A 1.765(3), Fe1-C3C 1.789(3), Fe1-C2B 1.797(3), Fe1-P1 2.011(1), Fe1-H1 1.48(2), P1-N2 1.673(2), P1-N5 1.676(2), N2-C3 1.406(3), C3-C4 1.330(4), C4-N5 1.386(3). data and a single-crystal XRD study (see ESI $\dagger$ ). The iron atom adopts trigonal-bipyramidal coordination like in $\mathbf{3 a}$, but the $\mathrm{Ph}_{3} \mathrm{Sn}$ and NHP ligands occupy now both axial positions, presumably due to steric reasons.

Electrophilic attack at iron is also observed upon treatment of $\mathrm{Na}[2]$ with one more equivalent of 1 . The reaction proceeds with spontaneous decarbonylation to yield bis-NHP complex $\mathbf{5}$ (Scheme 3) which is a rare example of a complex featuring two terminal phosphenium ligands coordinated to the same metal atom. ${ }^{24}$ A single-crystal XRD study (Fig. 3) reveals distorted tetrahedral coordination at iron, whereas the $\mathrm{Fe}-\mathrm{C}$ and $\mathrm{Fe}-\mathrm{P}$ bond lengths and the trigonal planar coordination at the phosphorus atoms are similar as in 2-4.

Computational studies on model complexes $3 \mathbf{a}^{\prime} / \mathbf{5}^{\prime}$ (with NMe instead of NDipp residues) imply a slight weakening of Fe-P bonds (Fe-P 2.047/2.017 ̊; WBI 1.20/1.33) compared to 2 ', which is mainly because of the $\mathrm{M} \rightarrow \mathrm{L} \pi$-bonding and creates an enlarged partial charge (1.01/1.19) on the NHP unit. These findings confirm the role of the phosphenium moieties as Fischer-carbene analogue ligands which exert their stabilizing influence by a combination of ambiphilic $\sigma$-donor/ $\pi$-acceptor and electrostatic interactions. A marked $\pi$-acceptor character of the NHP unit is once more highlighted by the

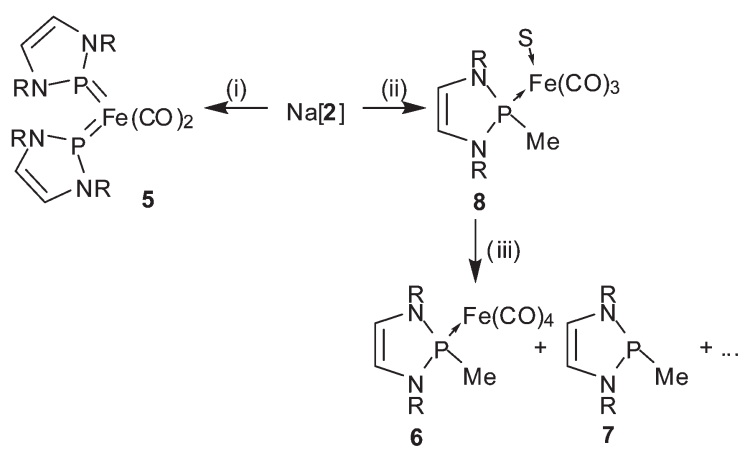

Scheme $3 \mathrm{R}=$ Dipp; $\mathrm{S}=$ nothing or solvent (THF); (i) 1 equiv. $1, \mathrm{THF}$, $-78^{\circ} \mathrm{C}, 2 \mathrm{~h}$; (ii) 1 equiv. Mel, THF, $-70^{\circ} \mathrm{C}$, r.t.; (iii) $-70^{\circ} \mathrm{C} \rightarrow$ r.t.

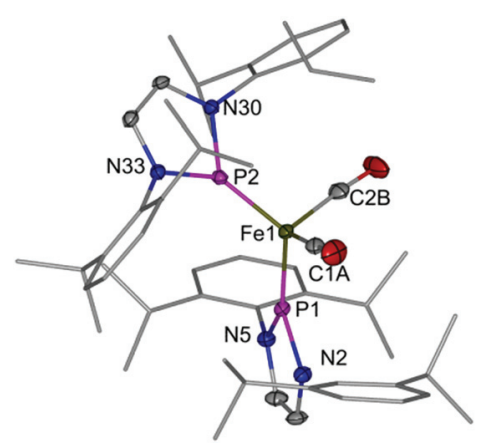

Fig. 3 Representation of the molecular structure of 5 in the crystal. $\mathrm{H}$ atoms were omitted for clarity. Selected bond lengths $(\AA)$ and angles $\left(^{\circ}\right)$ Fe1-C1A 1.766(3), Fe1-C2B 1.772(3), Fe1-P1 2.009(1), Fe1-P2 2.016(1), P1-N2 1.696(2), P1-N5 1.702(2), P2-N30 1.700(2), P2-N33 1.704(2), P1-Fe1-P2 126.1(1), other Fe-centred angles 103.4(1)-108.0(1). 
large blue shift of the $\nu$ CO modes of 3a (2014, 1960, $\left.1933 \mathrm{~cm}^{-1}\right)$ and $4\left(2064,1978,1909 \mathrm{~cm}^{-1}\right)$ in comparison with analogous phosphite complexes like $\left[\mathrm{HFe}(\mathrm{CO})_{3}\left\{\mathrm{P}(\mathrm{OMe})_{3}\right\}\right]^{-}\left(\mathrm{a}_{1^{-}}\right.$ and e-modes at 1941 and $1841 \mathrm{~cm}^{-1}$ (ref. 15b)) and $\left[\mathrm{Ph}_{3} \mathrm{SnFe}-\right.$ $\left.(\mathrm{CO})_{3}\left\{\mathrm{P}(\mathrm{OMe})_{3}\right\}\right]^{-}\left(\mathrm{a}_{1}{ }^{-}\right.$and e-modes at 1925 and $1820 \mathrm{~cm}^{-1}$ (ref. 19)), respectively. On the other hand, the observation of higher $\nu \mathrm{CO}$ frequencies in $\left[\mathrm{Fe}(\mathrm{CO})_{2}(\mathrm{NO})_{2}\right]^{25}\left(2092,2046 \mathrm{~cm}^{-1}\right)$ suggests that the $\pi$-acceptor capability of the NHP unit remains inferior to that of a nitrosyl.

In contrast to the cases described so far, the reaction of $\mathrm{Na}[2]$ with MeI (Scheme 3) affords no metal-functionalized product but a mixture of a P-alkylated phosphine complex 7 and its iron complex 6 which was isolated in modest yield and characterised by a single-crystal XRD study. The identity of both species was further established in situ from multinuclear NMR studies and verified by their independent synthesis (see Experimental). The observed product distribution implies that elemental iron or some iron-containing compounds are formed as by-products, even if none of these was directly identified.

The reaction leading to 6 and 7 seems appealing as it may at first glance be considered to involve nucleophilic reactivity of an electrophilic phosphorus atom. However, in view of a previous report by the group of Nakazawa on the assembly of a related P-alkylated ligand through migratory insertion of a phosphenium unit into a metal-alkyl bond, ${ }^{26}$ it is entirely possible that the initial electrophilic functionalization occurs at the iron site and the final products are formed in subsequent rearrangement steps.

In order to cast further light on these mechanistic aspects, we followed the reaction of $\mathrm{Na}[2]$ with $\mathrm{MeI}$ at low temperature by VT NMR spectroscopy. The ${ }^{1} \mathrm{H}$ and ${ }^{31} \mathrm{P}$ NMR spectra recorded immediately after mixing both reactants at $-70{ }^{\circ} \mathrm{C}$ disclosed that under these conditions a previously unobserved species 8 (Scheme 3) had formed as a major product (approx. $90 \%$ of all phosphorus-containing species by integration of the ${ }^{31} \mathrm{P}$ NMR spectrum) besides minor amounts of 6 and $7(<10 \%)$ and trace quantities of unidentified by-products. The composition of the reaction mixture did not change perceptibly as long as the temperature was kept below $-50{ }^{\circ} \mathrm{C}$. At this point, the onset of a slow and irreversible conversion of 8 into a mixture of 6 and 7 was noted. This process accelerated upon warming, and went eventually to completion after the sample had reached ambient temperature. Further spectroscopically observable intermediates were not detected. Since the initial product distribution varied somewhat (in a non-reproducible manner) between repeated experiments, we assume that $\mathbf{8}$ is the primary reaction product, and the initially present amounts of 6 and 7 are formed as a consequence of insufficient control of local temperature or concentration during the mixing of reactants.

The constitutional assignment of the intermediate 8 was feasible from the analysis of a set of one- and two-dimensional NMR spectra recorded at low temperature. The finding that the signals of the extra $\mathrm{CH}_{3}$ group $\left(\delta^{1} \mathrm{H}=2.02, \delta^{13} \mathrm{C}=26.7\right)$ do not show the negative chemical shifts which are typical of
Fe- $\mathrm{CH}_{3}$ units, ${ }^{26}$ but come close to those of the P-bound substituents in $6\left(\delta^{1} \mathrm{H}=1.96, \delta^{13} \mathrm{C}=29.5\right)$, gives a first indication that the methyl is bound, like in 6 and 7, to the phosphorus rather than the iron atom. This assignment is further supported by (i) the presence of two distinguishable anisochronic environments for the iPr-groups in the NDipp-substituents, which implies that the coordination at phosphorus is pyramidal or tetrahedral (as in 6, 7) rather than planar (as in 2-5), and (ii) the observation of ${ }^{1} \mathrm{H}$-NOESY cross peaks which connect the $\mathrm{CH}_{3}$-signal with both the signal of the $\mathrm{CH}$-atoms in the diazaphospholene ring and the signals of one anisochronic iPr-group (the one on the same side of the five-membered ring; see ESI $\dagger$ ). On this basis, we formulate the product as a complex in which the iron atom is bound to three carbonyls and the neutral phosphine 7 , and the remaining coordination site remains empty or is occupied by a solvent molecule (8, Scheme 3). Starting from this assignment, the conversion of $\mathbf{8}$ into a mixture of $\mathbf{6}$ and 7 is explained as the consequence of ligand extrusion/redistribution reactions which are common for carbonyl complexes that are coordinatively unsaturated or carry weakly bound solvent ligands.

Considering that the VT NMR studies provided no evidence for the formation of a metal functionalized species as a precursor to $\mathbf{8}$, we consider it likely that this species may indeed constitute the initial reaction product. Even if this interpretation seems at first glance counterintuitive, it is backed by the finding that the HOMO-1 of $2^{\prime}$ (which arises from mixing a filled metal-centred orbital with a $\sigma^{*}(\mathrm{PN})$ ligand orbital) contains a perceptible P-centred contribution, and the anion retains thus a certain degree of ambident character. It is currently under investigation if the attack of carbon-based electrophiles can be directed by steric effects.

\section{Conclusions}

In conclusion, we describe the successful synthesis of a NHP carbonyl ferrate which complements known cationic and neutral phosphenium complexes by a first anionic derivative. Structural and computational studies indicate that the ligand retains its electrophilic nature and shows no disposition to adopt phosphide-like character or formally oxidize the metal centre. Accordingly, the NHP ferrate reacts mainly as a metal centred nucleophile, but still retains some of the ambident character that is otherwise typical of neutral metallophosphenium complexes.

\section{Experimental}

\section{General conditions}

All manipulations were carried out under dry argon. Solvents were dried by standard procedures. NMR spectra were recorded on Bruker Avance AV 400 or AV 250 instruments $\left({ }^{1} \mathrm{H}: 400.1 /\right.$ 250.0 MHz, ${ }^{13} \mathrm{C}$ : $\left.100.5 / 62.9 \mathrm{MHz},{ }^{31} \mathrm{P}: 161.9 / 101.2 \mathrm{MHz}\right)$; chemical shifts were referenced to ext. TMS $\left({ }^{1} \mathrm{H},{ }^{13} \mathrm{C}\right), 85 \%$ 
$\mathrm{H}_{3} \mathrm{PO}_{4}\left(\Xi=40.480747 \mathrm{MHz},{ }^{31} \mathrm{P}\right)$. FT-IR spectra were recorded on a Thermo Scientific Nicolet iS5 instrument equipped with an iD5 ATR accessory. Elemental analyses were carried out using an Elementar Micro Cube. Melting points were determined with a Büchi B-545 melting point apparatus in sealed capillaries. Collman's reagent was prepared as described elsewhere. $^{27}$

\section{Syntheses}

$\mathrm{Na}[2]$ : (a) A solution of $\mathrm{Na}_{2}\left[\mathrm{Fe}(\mathrm{CO})_{4}\right](390 \mathrm{mg}, 1.12 \mathrm{mmol})$ in THF $(20 \mathrm{ml})$ was cooled in a dry ice/acetone bath to $-78{ }^{\circ} \mathrm{C}$. A solution of 1 (500 mg, $1.12 \mathrm{mmol})$ in THF (5 ml) was added dropwise. The solution was allowed to warm to r.t., stirred for $2 \mathrm{~h}$, and filtered. The filtrate was concentrated to a volume of approx. $5 \mathrm{ml}$. Addition of hexane $(15 \mathrm{ml})$ produced a brownred precipitate which was filtered off, washed with additional hexane, and dried under vacuum to give $312 \mathrm{mg}(48 \%)$ of a brown-red, air and moisture sensitive solid, m.p. $306^{\circ} \mathrm{C}$ (dec.).

(b) Solid $\mathrm{NaH}(8.7 \mathrm{mg}, 0.37 \mathrm{mmol})$ was added to a solution of complex 3 (200 mg, $365 \mu \mathrm{mol})$ in THF (10 ml THF). The mixture was stirred overnight. The solution was filtered to remove undissolved $\mathrm{NaH}$. The solvent was removed under reduced pressure. The remaining solid was washed with hexane and dried under vacuum to give $141 \mathrm{mg}(67 \%)$ of a brown-red, air and moisture sensitive solid, m.p. $306^{\circ} \mathrm{C}$ (dec.).

${ }^{31} \mathrm{P}\left\{{ }^{1} \mathrm{H}\right\}$ NMR $\left(d_{8}\right.$-THF): $\delta=211.1(\mathrm{~s}) .{ }^{1} \mathrm{H}$ NMR $\left(d_{8}\right.$-THF $) \delta=$ $7.21\left(\mathrm{~m}, 6 \mathrm{H}, \mathrm{C}_{6} H_{3}\right), 6.48\left(\mathrm{~d}, 2 \mathrm{H},=\mathrm{CH},{ }^{3} J_{\mathrm{PH}}=3.8 \mathrm{~Hz}\right), 3.48$ (sept, $\left.4 \mathrm{H}, \mathrm{CH}\left(\mathrm{CH}_{3}\right)_{2},{ }^{3} \mathrm{~J}_{\mathrm{HH}}=6.9 \mathrm{~Hz}\right), 1.37$ (d, $12 \mathrm{H}, \mathrm{CH}\left(\mathrm{CH}_{3}\right)_{2}$, $\left.{ }^{3} J_{\mathrm{HH}}=6.9 \mathrm{~Hz}\right), 1.21\left(\mathrm{~d}, 12 \mathrm{H}, \mathrm{CH}\left(\mathrm{CH}_{3}\right)_{2},{ }^{3} J_{\mathrm{HH}}=6.9 \mathrm{~Hz}\right) \cdot{ }^{13} \mathrm{C}\left\{{ }^{1} \mathrm{H}\right\}$ NMR $\left(d_{8}\right.$-THF) $\delta=229.2\left(\mathrm{~d},{ }^{2} J_{\mathrm{PC}}=10.8 \mathrm{~Hz}, \mathrm{CO}\right), 148.1(\mathrm{~s}, p$-C), $137.6\left(\mathrm{~d},{ }^{2} J_{\mathrm{PC}}=6.9 \mathrm{~Hz}, \mathrm{i}-\mathrm{C}\right), 127.8\left(\mathrm{~d},{ }^{3} J_{\mathrm{PC}}=3.9 \mathrm{~Hz}, o-\mathrm{C}\right), 123.4$ (s, $m$-C), $122.3\left(\mathrm{~d},{ }^{2} J_{\mathrm{PC}}=4.6 \mathrm{~Hz},=\mathrm{CH}\right), 28.9\left(\mathrm{~s}, C\left(\mathrm{CH}_{3}\right)_{2}\right), 23.5$ (s, $\left.\mathrm{CH}_{3}\right), 23.3\left(\mathrm{~s}, \mathrm{CH}_{3}\right)$. IR: $\tilde{\nu}=1912,1834,1767 \mathrm{~cm}^{-1}(\nu \mathrm{CO}) .{ }^{1} \mathrm{H}$ and ${ }^{13} \mathrm{C}$ NMR spectra disclosed the presence of varying amounts of THF (presumably for the solvation of $\mathrm{Na}^{+}$) which precluded obtaining a consistent elemental analysis.

$\left[\mathrm{PPh}_{4}\right][2]$ : A solution of $\mathrm{Na}[2]$ was prepared as described above from 3 (200 mg, $365 \mu \mathrm{mol})$ and $\mathrm{NaH}(8.7 \mathrm{mg}$, $0.37 \mathrm{mmol})$. Solid $\left[\mathrm{Ph}_{4} \mathrm{P}\right] \mathrm{Cl}(137 \mathrm{mg}, 365 \mu \mathrm{mol})$ was added with stirring. The resulting mixture was filtered to remove precipitated NaCl. The filtrate was evaporated to dryness and the residue was dissolved in a minimum amount of THF. Storing the solution at $4{ }^{\circ} \mathrm{C}$ gave $230 \mathrm{mg}$ (71\%) of orange crystals, m.p. $>350{ }^{\circ} \mathrm{C}$ (dec.).

${ }^{31} \mathrm{P}\left\{{ }^{1} \mathrm{H}\right\}$ NMR $\left(d_{8}\right.$-THF): $\delta=197.9$ (s, P-Fe), $22.7\left(\mathrm{~s}, \mathrm{PPh}_{4}\right) \cdot{ }^{1} \mathrm{H}$ NMR $\left(d_{8}\right.$-THF) $\delta=7.73\left(\mathrm{~m}, 4 \mathrm{H}, \mathrm{C}_{6} H_{5}\right), 7.60\left(\mathrm{~m}, 16 \mathrm{H}, \mathrm{C}_{6} H_{5}\right)$, $7.01\left(\mathrm{~m}, 6 \mathrm{H}, \mathrm{C}_{6} H_{3}\right), 6.19\left(\mathrm{~d}, 2 \mathrm{H},=\mathrm{CH},{ }^{3} J_{\mathrm{PH}}=3.2 \mathrm{~Hz}\right), 3.41$ (sept, $\left.4 \mathrm{H}, \mathrm{CH}\left(\mathrm{CH}_{3}\right)_{2},{ }^{3} \mathrm{~J}_{\mathrm{HH}}=6.9 \mathrm{~Hz}\right), 1.19\left(\mathrm{~d}, 12 \mathrm{H}, \mathrm{CH}\left(\mathrm{CH}_{3}\right)_{2}\right.$, $\left.{ }^{3} J_{\mathrm{HH}}=6.9 \mathrm{~Hz}\right), 1.04\left(\mathrm{~d}, 12 \mathrm{H}, \mathrm{CH}\left(\mathrm{CH}_{3}\right)_{2},{ }^{3} J_{\mathrm{HH}}=6.9 \mathrm{~Hz}\right) \cdot{ }^{13} \mathrm{C}\left\{{ }^{1} \mathrm{H}\right\}$ NMR $\left(d_{8}\right.$-THF) $\delta=229.2\left(\mathrm{~d},{ }^{2} J_{\mathrm{PC}}=13.2 \mathrm{~Hz}, \mathrm{CO}\right), 147.4(\mathrm{~s}, o-\mathrm{C})$, $137.6\left(\mathrm{~d},{ }^{2} J_{\mathrm{PC}}=6.4 \mathrm{~Hz}, \mathrm{i}-\mathrm{C}\right), 134.8\left(\mathrm{~d},{ }^{4} J_{\mathrm{PC}}=2.95 \mathrm{~Hz}, p-\mathrm{C}\left(\mathrm{PPh}_{4}\right)\right.$ ), $134.3\left(\mathrm{~d},{ }^{2} J_{\mathrm{PC}}=10.5 \mathrm{~Hz}, o-\mathrm{C}\left(\mathrm{PPh}_{4}\right)\right), 130.0\left(\mathrm{~d},{ }^{3} J_{\mathrm{PC}}=12.9 \mathrm{~Hz}\right.$, $\left.m-\mathrm{C}\left(\mathrm{PPh}_{4}\right)\right), 126.6(\mathrm{~s}, p-\mathrm{C}), 122.5(\mathrm{~s}, m-\mathrm{C}), 120.6\left(\mathrm{~d},{ }^{2} J_{\mathrm{PC}}=4.6\right.$ $\mathrm{Hz},=\mathrm{CH}), 28.0\left(\mathrm{~s}, \mathrm{CH}\left(\mathrm{CH}_{3}\right)_{2}\right), 23.8\left(\mathrm{~s}, \mathrm{CH}_{3}\right), 22.8\left(\mathrm{~s}, \mathrm{CH}_{3}\right)$. IR: $\tilde{\nu}=1894,1813,1798 \mathrm{~cm}^{-1}(\nu \mathrm{CO})$. The high sensitivity of the product precluded to obtain a meaningful elemental analysis. 3a, b: (a) $\mathrm{K}\left[\mathrm{HFe}(\mathrm{CO})_{4}\right](234 \mathrm{mg}, 1.12 \mathrm{mmol})$ and THF $(3 \mathrm{ml})$ were introduced into a Schlenk flask and stirred for $10 \mathrm{~min}$ at r.t. The flask was then cooled to $-78{ }^{\circ} \mathrm{C}$ in a dry ice-acetone bath, and a solution of $\mathbf{1}(500 \mathrm{mg}, 1.12 \mathrm{mmol})$ in THF (5 ml) was added dropwise. The solution was allowed to warm to r.t. and stirred for another $2 \mathrm{~h}$. The solvent was removed under reduced pressure. The remaining black solid was extracted with hexane. The mixture was filtered and evaporated to dryness. The residue was dissolved in a minimum amount of hexane. The resulting solution was stored at $4{ }^{\circ} \mathrm{C}$ to give $573 \mathrm{mg}(93 \%)$ of $3 \mathbf{a}$ as yellow crystals, m.p. $>350{ }^{\circ} \mathrm{C}$ (dec.).

(b) A solution of $\mathrm{Na}[2]$ (5 mg) in $\mathrm{THF}^{-\mathrm{d}_{8}}$ was treated with a drop of glacial acetic acid or acetic acid- $\mathrm{d}_{4}$. The formed products $(\mathbf{3 a}, \mathbf{b})$ were identified by their NMR data.

3a: ${ }^{31} \mathrm{P}\left\{{ }^{1} \mathrm{H}\right\}$ NMR $\left(\mathrm{C}_{6} \mathrm{D}_{6}\right): \delta=225.0(\mathrm{~s}) .{ }^{1} \mathrm{H}$ NMR $\left(\mathrm{C}_{6} \mathrm{D}_{6}\right): \delta=$ $7.18\left(\mathrm{~m}, 6 \mathrm{H}, \mathrm{C}_{6} H_{3}\right), 6.13\left(\mathrm{~d}, 2 \mathrm{H},{ }^{3} J_{\mathrm{PH}}=6.7 \mathrm{~Hz},=\mathrm{CH}\right), 3.07$ (sept, $\left.4 \mathrm{H},{ }^{3} J_{\mathrm{HH}}=6.9 \mathrm{~Hz}, \mathrm{CH}\left(\mathrm{CH}_{3}\right)_{2}\right), 1.36\left(\mathrm{~d}, 12 \mathrm{H},{ }^{3} J_{\mathrm{HH}}=6.9\right.$ $\left.\left.\mathrm{Hz}, \mathrm{CH}\left(\mathrm{CH}_{3}\right)_{2}\right), 1.10\left(\mathrm{~d}, 12 \mathrm{H},{ }^{3} \mathrm{~J}_{\mathrm{HH}}=6.9 \mathrm{~Hz}, \mathrm{CH}\left(\mathrm{CH}_{3}\right)_{2}\right)\right),-8.88$ (d, $\left.1 \mathrm{H},{ }^{2} J_{\mathrm{PH}}=88.1 \mathrm{~Hz}, \mathrm{FeH}\right) .{ }^{13} \mathrm{C}\left\{{ }^{1} \mathrm{H}\right\} \operatorname{NMR}\left(\mathrm{C}_{6} \mathrm{D}_{6}\right): \delta=214.30$ $\left(\mathrm{d},{ }^{2} J_{\mathrm{PC}}=13.6 \mathrm{~Hz}, \mathrm{CO}\right), 147.0\left(\mathrm{~d},{ }^{2} J_{\mathrm{PC}}=3.0 \mathrm{~Hz}, o-\mathrm{C}\right), 132.9(\mathrm{~d}$, $\left.{ }^{3} J_{\mathrm{PC}}=5.9 \mathrm{~Hz}, \mathrm{i}-\mathrm{C}\right), 130.2\left(\mathrm{~d},{ }^{5} J_{\mathrm{PC}}=1.4 \mathrm{~Hz}, p-\mathrm{C}\right), 124.4\left(\mathrm{~d},{ }^{4} J_{\mathrm{PC}}=\right.$ $1.0 \mathrm{~Hz}, m-\mathrm{C}), 123.6$ (d, $\left.{ }^{2} J_{\mathrm{PC}}=1.7 \mathrm{~Hz},=\mathrm{CH}\right), 28.9\left(\mathrm{~s}, C\left(\mathrm{CH}_{3}\right)_{2}\right)$, $24.4\left(\mathrm{~s}, C \mathrm{H}_{3}\right), 23.0\left(\mathrm{~s}, C \mathrm{H}_{3}\right)$. IR: $\tilde{\nu}=2014,1960,1933 \mathrm{~cm}^{-1}$ $(\nu \mathrm{CO})$. Elemental analysis: calcd for $\mathrm{C}_{29} \mathrm{H}_{37} \mathrm{FeN}_{2} \mathrm{O}_{3} \mathrm{P}$ (548.19): C 63.51, H 6.80, N 5.11; found C 63.06, H 6.86, N 5.09.

3b: ${ }^{31} \mathrm{P}\left\{{ }^{1} \mathrm{H}\right\}$ NMR $\left(\mathrm{d}_{8}\right.$-THF $): \delta=228.1\left(\mathrm{t},{ }^{2} J_{\mathrm{PD}}=13.5 \mathrm{~Hz}\right) \cdot{ }^{1} \mathrm{H}$ NMR ( $\mathrm{d}_{8}$-THF): $\delta=7.36\left(\mathrm{~m}, 2 \mathrm{H}, \mathrm{C}_{6} \mathrm{H}_{3}\right), 7.24\left(\mathrm{~m}, 4 \mathrm{H}, \mathrm{C}_{6} \mathrm{H}_{3}\right)$, $6.88\left(\mathrm{~d}, 2 \mathrm{H},{ }^{3} \mathrm{~J}_{\mathrm{PH}}=6.8 \mathrm{~Hz},=\mathrm{CH}\right), 2.89$ (sept, $4 \mathrm{H}, \mathrm{CH}\left(\mathrm{CH}_{3}\right)_{2}$ $\left.{ }^{3} J_{\mathrm{HH}}=6.8 \mathrm{~Hz}\right), 1.19\left(\mathrm{~d}, 12 \mathrm{H}, \mathrm{CH}\left(\mathrm{CH}_{3}\right)_{2},{ }^{3} J_{\mathrm{HH}}=6.8 \mathrm{~Hz}\right), 1.11(\mathrm{~d}$, $\left.\left.12 \mathrm{H}, \mathrm{CH}\left(\mathrm{CH}_{3}\right)_{2}\right),{ }^{3} \mathrm{JHH}_{\mathrm{HH}}=6.8 \mathrm{~Hz}\right)$.

4: A solution of $\mathrm{Na}[2]$ was prepared by dissolving complex 3a (30 mg, $54 \mu \mathrm{mol})$ in $\mathrm{THF}^{-\mathrm{d}_{8}}$ and deprotonating with $\mathrm{NaH}$ (1.3 mg, $54 \mu \mathrm{mol})$. After quantitative conversion had been established by NMR spectroscopy, triphenyltin chloride (20 mg, $54 \mu \mathrm{mol}$ ) was added. After $5 \mathrm{~min}$, the reaction was complete, and precipitated solids were removed via decantation. After the evaporation of $\mathrm{d}_{8}$-THF, the product was isolated as red crystals, yield $47 \mathrm{mg}$ (93\%), m.p. $>350{ }^{\circ} \mathrm{C}$ (dec.).

${ }^{31} \mathrm{P}\left\{{ }^{1} \mathrm{H}\right\}$ NMR $\left(\mathrm{d}_{8}\right.$-THF): $\delta=251.2\left(\mathrm{~s},{ }^{2} J_{119 / 117 \mathrm{SnP}}=220 / 211\right.$ $\mathrm{Hz}) .{ }^{1} \mathrm{H}$ NMR (d $\mathrm{d}_{8}$-THF): $\delta=7.45-7.05\left(\mathrm{~m}, 23 \mathrm{H}, \mathrm{C}_{6} H_{3}, \mathrm{C}_{6} H_{5}\right.$ and $=\mathrm{CH}$ ), 3.13 (sept, $\left.4 \mathrm{H},{ }^{3} J_{\mathrm{HH}}=6.8 \mathrm{~Hz}, \mathrm{CH}\left(\mathrm{CH}_{3}\right)_{2}\right), 1.24(\mathrm{~d}, 6 \mathrm{H}$, $\left.{ }^{3} J_{\mathrm{HH}}=6.8 \mathrm{~Hz}, \mathrm{CH}\left(\mathrm{CH}_{3}\right)_{2}\right), 1.23\left(\mathrm{~d}, 6 \mathrm{H},{ }^{3} J_{\mathrm{HH}}=6.7 \mathrm{~Hz}, \mathrm{CH}\left(\mathrm{CH}_{3}\right)_{2}\right)$. ${ }^{13} \mathrm{C}\left\{{ }^{1} \mathrm{H}\right\}$ NMR ( $\mathrm{d}_{8}$-THF): $\delta=214.7\left(\mathrm{~d}, \mathrm{CO},{ }^{2} J_{\mathrm{PC}}=8.8 \mathrm{~Hz}\right), 147.0$ $\left(\mathrm{d},{ }^{2} J_{\mathrm{PC}}=3.4 \mathrm{~Hz}, \mathrm{i}-\mathrm{C}\right), 145.2\left(\mathrm{~d},{ }^{3} J_{\mathrm{PC}}=4.1 \mathrm{~Hz}, o-\mathrm{C}\right), 137.0(\mathrm{~s}$, $o$-C), $133.4\left(\mathrm{~d},{ }^{3} J_{\mathrm{PC}}=5.4 \mathrm{~Hz}, o-\mathrm{C}\right), 130.5\left(\mathrm{~d},{ }^{4} J_{\mathrm{PC}}=1.3 \mathrm{~Hz}, m-\mathrm{C}\right)$, $127.9\left(\mathrm{~d},{ }^{5} J_{\mathrm{PC}}=1.7 \mathrm{~Hz}, p-\mathrm{C}\right), 127.69(\mathrm{~s}, m-\mathrm{C}), 127.68(\mathrm{~s}, p-\mathrm{C})$, 124.6 (s, i-C), $29.4\left(\mathrm{~s}, \mathrm{C}\left(\mathrm{CH}_{3}\right)_{2}\right), 24.8\left(\mathrm{~s}, \mathrm{CH}_{3}\right), 22.8\left(\mathrm{~s}, \mathrm{CH}_{3}\right)$. IR: $\tilde{\nu}=2064,1978,1909 \mathrm{~cm}^{-1}(\nu \mathrm{CO})$. Analytical data were found to show a strong dependence on the combustion conditions which implied that even at elevated temperatures no complete combustion could be achieved. As several attempts to establish optimum conditions failed, no meaningful elemental analysis was obtained. The homogeneity of the product was established using spectral data (see ESI $\dagger$ ).

5: (a) A solution of $\mathrm{Na}_{2}\left[\mathrm{Fe}(\mathrm{CO})_{4}\right](390 \mathrm{mg}, 1.12 \mathrm{mmol})$ in THF $(20 \mathrm{ml})$ was cooled in a dry ice/acetone bath to $-78^{\circ} \mathrm{C}$. 
A solution of 1 (500 mg, $1.12 \mathrm{mmol})$ in THF (5 ml) was added dropwise with stirring. The solution was allowed to warm to r.t., stirred for $2 \mathrm{~h}$, and filtered. The solution was again cooled to $-78{ }^{\circ} \mathrm{C}$, and another equivalent of 1 (500 $\mathrm{mg}, 1.12 \mathrm{mmol}$ ) was added. Stirring was continued for $2 \mathrm{~h}$ during which the mixture was allowed to warm to r.t. Solids were then filtered off, and the solvent was removed under reduced pressure. The remaining dark solid was treated with hexane, the mixture filtered, and the filtrate evaporated to dryness. The residue was dissolved in a minimum amount of hexane and stored at $4{ }^{\circ} \mathrm{C}$, to give $570 \mathrm{mg}(55 \%)$ of red crystals, m.p. $>350{ }^{\circ} \mathrm{C}$ (dec.).

(b) Alternatively, 5 was directly accessible from reaction of Collman's reagent with 2 equiv. of 1: $\mathrm{Na}_{2}\left[\mathrm{Fe}(\mathrm{CO})_{4}\right](390 \mathrm{mg}$, $1.12 \mathrm{mmol})$ and THF $(20 \mathrm{ml})$ were introduced into a Schlenk flask and stirred for $10 \mathrm{~min}$ at r.t. The flask was then cooled to $-78{ }^{\circ} \mathrm{C}$ in a dry ice-acetone bath, and a solution of 1 (1.00 g, $2.25 \mathrm{mmol})$ in THF (10 ml) was added dropwise. The mixture was allowed to warm to r.t. and stirred for another $2 \mathrm{~h}$. The solvent was removed under reduced pressure and the remaining dark solid was treated with hexane. The mixture was filtered and the filtrate was evaporated to dryness. The residue was dissolved in a minimum amount of hexane and stored at $4{ }^{\circ} \mathrm{C}$, to give $747 \mathrm{mg}(72 \%)$ of red crystals, m.p. $>350{ }^{\circ} \mathrm{C}$ (dec.).

${ }^{31} \mathrm{P}\left\{{ }^{1} \mathrm{H}\right\} \operatorname{NMR}\left(\mathrm{C}_{6} \mathrm{D}_{6}\right): \delta=217.7(\mathrm{~s}) .{ }^{1} \mathrm{H}$ NMR $\left(\mathrm{C}_{6} \mathrm{D}_{6}\right): \delta=7.19$ $\left(\mathrm{m}, 2 \mathrm{H}, \mathrm{C}_{6} \mathrm{H}_{3}\right), 7.09\left(\mathrm{~m}, 4 \mathrm{H}, \mathrm{C}_{6} \mathrm{H}_{3}\right), 6.09(\mathrm{~s}, 2 \mathrm{H},=\mathrm{CH}), 3.25$ (sept, $\left.4 \mathrm{H},{ }^{3} J_{\mathrm{HH}}=6.8 \mathrm{~Hz}, \mathrm{CH}\left(\mathrm{CH}_{3}\right)_{2}\right), 1.23\left(\mathrm{~d}, 12 \mathrm{H},{ }^{3} J_{\mathrm{HH}}=6.8\right.$ $\left.\mathrm{Hz}, \mathrm{CH}\left(\mathrm{CH}_{3}\right)_{2}\right), 1.12\left(\mathrm{~d}, 12 \mathrm{H},{ }^{3} J_{\mathrm{HH}}=6.8 \mathrm{~Hz}, \mathrm{CH}\left(\mathrm{CH}_{3}\right)_{2}\right) .{ }^{13} \mathrm{C}\left\{{ }^{1} \mathrm{H}\right\}$ NMR $\left(\mathrm{C}_{6} \mathrm{D}_{6}\right): \delta=222.4$ (s, CO), 147.7 (s,o-C), 136.6 (s, i-C), 129.5 (s, p-C), 124.8 (s, = $\mathrm{CH}), 124.6(\mathrm{~s}, m-\mathrm{C}), 29.2\left(\mathrm{~s}, C\left(\mathrm{CH}_{3}\right)_{2}\right)$, 25.6(s, $\left.\mathrm{CH}_{3}\right), 24.0\left(\mathrm{~s}, \mathrm{CH}_{3}\right)$. IR: $\tilde{\nu}=1930,1883 \mathrm{~cm}^{-1}(\nu \mathrm{CO})$. Analytical data were found to show a strong dependence on the combustion conditions which implied that even at elevated temperatures no complete combustion could be achieved. As several attempts to establish optimum conditions failed, no meaningful elemental analysis was obtained. The homogeneity of the product was established using spectral data (see ESI $\dagger$ ).

Reaction of $\mathrm{Na}$ [2] with MeI. (a) A solution of $\mathrm{Na}$ [2] was prepared as described above (variant (a)) from $\mathrm{Na}_{2}\left[\mathrm{Fe}(\mathrm{CO})_{4}\right]$ (390 mg, $1.12 \mathrm{mmol}$ ) and 1 (500 mg, $1.12 \mathrm{mmol}$ ). After quantitative formation of the product had been established by NMR, the solution was cooled to $-78{ }^{\circ} \mathrm{C}$, and freshly distilled MeI (160 mg, $1.12 \mathrm{mmol}$ ) was added dropwise. The solution was then allowed to warm to r.t. and stirred for another $2 \mathrm{~h} . \mathrm{A}^{31} \mathrm{P}$ NMR spectrum displayed signals of 6 (169.4 ppm) and 7 (110.5 ppm; relative signal strengths were found to vary somewhat between different experiments; see below). The solvent was removed under reduced pressure and the remaining solid was treated with hexane. The mixture was filtered and the filtrate was evaporated to dryness. The residue was dissolved in a minimum amount of hexane and stored at $4{ }^{\circ} \mathrm{C}$, to give 6 as dark red crystals, m.p. $>350{ }^{\circ} \mathrm{C}$ (dec.); yield $35 \mathrm{mg}(53 \%)$ in a typical reaction.

(b) A solution of $\mathrm{Na}[2](30 \mathrm{mg}, 53 \mu \mathrm{mol})$ in $\mathrm{d}_{8}$-THF $(0.4 \mathrm{ml})$ was placed in an NMR tube equipped with a Teflon-coated septum and cooled to $-70{ }^{\circ} \mathrm{C}$. A slight excess of MeI $(0.10 \mathrm{ml}$ of a $0.54 \mathrm{M}$ stock solution containing $7.5 \mathrm{mg} / 54 \mu \mathrm{mol}$ of reagent) was added via a syringe. Recording of multinuclear $\left({ }^{1} \mathrm{H},{ }^{13} \mathrm{C},{ }^{31} \mathrm{P}\right) \mathrm{NMR}$ spectra at $-70{ }^{\circ} \mathrm{C}$ immediately after mixing revealed the presence of a major product identified as complex 8 (approx. 90\% of phosphorus-containing species by integration of the ${ }^{31} \mathrm{P}$ NMR signals) besides minor amounts of 6 and $7(<10 \%$, presumably formed as a consequence of insufficient control of local temperature or concentration during the mixing process) and trace quantities of unidentified by-products. Monitoring the further progress of the reaction during slow warming to r.t. allowed us to establish that 8 decays to yield a mixture of 6 and 7. No further intermediates were spectroscopically observable during this process.

6: ${ }^{31} \mathrm{P}\left\{{ }^{1} \mathrm{H}\right\} \operatorname{NMR}\left(\mathrm{C}_{6} \mathrm{D}_{6}\right): \delta=169.4(\mathrm{~s}) .{ }^{1} \mathrm{H}$ NMR $\left(\mathrm{C}_{6} \mathrm{D}_{6}\right): \delta=$ $7.07\left(\mathrm{~m}, 6 \mathrm{H}, \mathrm{C}_{6} H_{3}\right), 5.76\left(\mathrm{~d}, 2 \mathrm{H},{ }^{3} J_{\mathrm{PH}}=11.0 \mathrm{~Hz},=\mathrm{CH}\right), 3.75$ (sept, $2 \mathrm{H},{ }^{3} \mathrm{~J}_{\mathrm{HH}}=6.9 \mathrm{~Hz}, \mathrm{CH}\left(\mathrm{CH}_{3}\right)_{2}$ ), 3.41 (sept, $2 \mathrm{H},{ }^{3} J_{\mathrm{HH}}=7.0$ $\left.\mathrm{Hz}, \mathrm{CH}\left(\mathrm{CH}_{3}\right)_{2}\right), 1.96\left(\mathrm{~d}, 3 \mathrm{H},{ }^{2} J_{\mathrm{PH}}=5.2 \mathrm{~Hz}, \mathrm{PCH}_{3}\right), 1.48(\mathrm{~d}, 6 \mathrm{H}$, $\left.{ }^{3} J_{\mathrm{HH}}=6.8 \mathrm{~Hz}, \mathrm{CH}\left(\mathrm{CH}_{3}\right)_{2}\right), 1.25\left(\mathrm{~d}, 6 \mathrm{H},{ }^{3} J_{\mathrm{HH}}=6.8 \mathrm{~Hz}, \mathrm{CH}\right.$ $\left.\left(\mathrm{CH}_{3}\right)_{2}\right), 1.16\left(\mathrm{~d}, 6 \mathrm{H},{ }^{3} \mathrm{~J}_{\mathrm{HH}}=6.7 \mathrm{~Hz}, \mathrm{CH}\left(\mathrm{CH}_{3}\right)_{2}\right), 1.08(\mathrm{~d}, 6 \mathrm{H}$, $\left.{ }^{3} J_{\mathrm{HH}}=6.7 \mathrm{~Hz}, \mathrm{CH}\left(\mathrm{CH}_{3}\right)_{2}\right) \cdot{ }^{13} \mathrm{C}\left\{{ }^{1} \mathrm{H}\right\} \operatorname{NMR}\left(\mathrm{C}_{6} \mathrm{D}_{6}\right): \delta=212.1(\mathrm{~d}$, $\left.{ }^{2} J_{\mathrm{PC}}=16.9 \mathrm{~Hz}, \mathrm{CO}\right), 148.5\left(\mathrm{~d},{ }^{3} J_{\mathrm{PC}}=1.9 \mathrm{~Hz}, o-\mathrm{C}\right), 134.2\left(\mathrm{~d},{ }^{2} J_{\mathrm{PC}}=\right.$ $4.6 \mathrm{~Hz}, \mathrm{i}-\mathrm{C}$ ), 128.0 (d, $\left.{ }^{5} J_{\mathrm{PC}}=1.1 \mathrm{~Hz}, p-\mathrm{C}\right), 123.0$ (s, $m$-C), 119.9 $\left(\mathrm{d},{ }^{2} \mathrm{~J}_{\mathrm{PC}}=2.7 \mathrm{~Hz},=\mathrm{CH}\right), 29.5\left(\mathrm{~s}, \mathrm{PCH}_{3}\right), 28.2\left(\mathrm{~s}, \mathrm{C}\left(\mathrm{CH}_{3}\right)_{2}\right), 27.6$ $\left(\mathrm{s}, \mathrm{C}\left(\mathrm{CH}_{3}\right)_{2}\right), 26.2\left(\mathrm{~s}, \mathrm{CH}_{3}\right), 24.7\left(\mathrm{~s}, \mathrm{CH}_{3}\right), 21.6\left(\mathrm{~s}, \mathrm{CH}_{3}\right), 21.1$ (s, $\left.\mathrm{CH}_{3}\right)$. IR: $\tilde{\nu}=2039,1963,1917 \mathrm{~cm}^{-1}(\nu \mathrm{CO})$.

8: ${ }^{31} \mathrm{P}\left\{{ }^{1} \mathrm{H}\right\}$ NMR $\left(\mathrm{d}_{8}-\mathrm{THF}, 203 \mathrm{~K}\right): \delta=191.3(\mathrm{~s}) .{ }^{1} \mathrm{H}$ NMR $\left(\mathrm{d}_{8^{-}}\right.$ THF, $253 \mathrm{~K}): \delta=7.22-7.10\left(\mathrm{~m}, 6 \mathrm{H}, \mathrm{C}_{6} H_{3}\right), 5.97\left(\mathrm{~d}, 2 \mathrm{H},{ }^{3} J_{\mathrm{PH}}=\right.$ $7.6 \mathrm{~Hz},=\mathrm{CH}$ ), 3.78 (sept, $\left.2 \mathrm{H},{ }^{3} J_{\mathrm{HH}}=6.6 \mathrm{~Hz}, \mathrm{CH}\left(\mathrm{CH}_{3}\right)_{2}\right), 3.65$ (sept, $\left.2 \mathrm{H},{ }^{3} J_{\mathrm{HH}}=6.6 \mathrm{~Hz}, \mathrm{CH}\left(\mathrm{CH}_{3}\right)_{2}\right), 2.02\left(\mathrm{~d}, 3 \mathrm{H},{ }^{2} J_{\mathrm{PH}}=3.6 \mathrm{~Hz}\right.$, $\left.\mathrm{PCH}_{3}\right), 1.43\left(\mathrm{~d}, 6 \mathrm{H},{ }^{3} J_{\mathrm{HH}}=6.6 \mathrm{~Hz}, \mathrm{CH}\left(\mathrm{CH}_{3}\right)_{2}\right), 1.34(\mathrm{~d}, 6 \mathrm{H}$, $\left.{ }^{3} J_{\mathrm{HH}}=6.6 \mathrm{~Hz}, \mathrm{CH}\left(\mathrm{CH}_{3}\right)_{2}\right), 1.20\left(\mathrm{~d}, 6 \mathrm{H},{ }^{3} J_{\mathrm{HH}}=6.7 \mathrm{~Hz}, \mathrm{CH}\right.$ $\left.\left(\mathrm{CH}_{3}\right)_{2}\right), 1.13\left(\mathrm{~d}, 6 \mathrm{H},{ }^{3} J_{\mathrm{HH}}=6.7 \mathrm{~Hz}, \mathrm{CH}\left(\mathrm{CH}_{3}\right)_{2}\right) .{ }^{13} \mathrm{C}\left\{{ }^{1} \mathrm{H}\right\} \mathrm{NMR}$ $\left(\mathrm{d}_{8}\right.$-THF, $\left.203 \mathrm{~K}\right): \delta=217.7$ (d, $\left.{ }^{2} J_{\mathrm{PC}}=27.7 \mathrm{~Hz}, \mathrm{CO}\right), 149.3(\mathrm{~s}, o-\mathrm{C})$, 147.9 (s, o-C), 138.9 (d, $\left.{ }^{2} J_{\mathrm{PC}}=5.4 \mathrm{~Hz}, \mathrm{i}-\mathrm{C}\right), 128.0$ (s, $p$-C), 123.9 (s, $m$-C), $123.0(\mathrm{~s}, m-\mathrm{C}), 120.2(\mathrm{~s},=\mathrm{CH}), 28.9\left(\mathrm{~s}, C\left(\mathrm{CH}_{3}\right)_{2}\right), 28.6$ $\left(\mathrm{s}, \mathrm{C}\left(\mathrm{CH}_{3}\right)_{2}\right), 27.6\left(\mathrm{~s}, \mathrm{CH}_{3}\right), 26.7\left(\mathrm{~d},{ }^{1} J_{\mathrm{PC}}=26 \mathrm{~Hz}, \mathrm{PCH}_{3}\right), 25.0(\mathrm{~s}$, $\left.\mathrm{CH}_{3}\right), 22.4$ (s, $\left.2 \mathrm{CH}_{3}\right)$.

Independent synthesis of 6 and 7. A solution of 1 (1.00 g, $2.25 \mathrm{mmol}$ ) in $\mathrm{Et}_{2} \mathrm{O}$ was added dropwise to a solution of MeMgI (374 mg, $2.25 \mathrm{mmol}$ ) in $\mathrm{Et}_{2} \mathrm{O}$. The mixture was stirred for $18 \mathrm{~h}$. The solvent was then removed under reduced pressure, the solid residue taken up in hexane, and the resulting mixture was filtered. The filtrate was evaporated to dryness under reduced pressure to yield crude 7 (340 $\mathrm{mg}, 0.73 \mathrm{mmol}$ ) which was identified using multinuclear $\left({ }^{1} \mathrm{H},{ }^{13} \mathrm{C},{ }^{31} \mathrm{P}\right) \mathrm{NMR}$ data. The phosphine was then dissolved in toluene, solid $\mathrm{Fe}_{2} \mathrm{CO}_{9}(260 \mathrm{mg}, 0.73 \mathrm{mmol})$ was added at r.t., and the resulting mixture was stirred overnight. Volatiles were removed under reduced pressure and the remaining solid was taken up in hexane. Filtration and evaporation of the filtrate to dryness gave $375 \mathrm{mg}(87 \%)$ of brown-red crystals of 6, m.p. $>350{ }^{\circ} \mathrm{C}$ (dec.).

7: ${ }^{31} \mathrm{P}\left\{{ }^{1} \mathrm{H}\right\}$ NMR $\left(\mathrm{C}_{6} \mathrm{D}_{6}\right): \delta=111.9$ (s). ${ }^{1} \mathrm{H}$ NMR $\left(\mathrm{C}_{6} \mathrm{D}_{6}\right): \delta=$ 7.2-7.1 (m, $\left.6 \mathrm{H}, \mathrm{C}_{6} \mathrm{H}_{3}\right), 5.74\left(\mathrm{~d}, 2 \mathrm{H},{ }^{3} \mathrm{~J}_{\mathrm{PH}}=2.0 \mathrm{~Hz},=\mathrm{CH}\right), 3.83$ (dsept, $2 \mathrm{H},{ }^{3} J_{\mathrm{HH}}=6.8 \mathrm{~Hz},{ }^{5} J_{\mathrm{PH}}=3.8 \mathrm{~Hz}, \mathrm{CH}\left(\mathrm{CH}_{3}\right)_{2}$ ), 3.65 (sept, $\left.2 \mathrm{H},{ }^{3} J_{\mathrm{HH}}=6.8 \mathrm{~Hz}, \mathrm{CH}\left(\mathrm{CH}_{3}\right)_{2}\right), 1.43\left(\mathrm{~d}, 6 \mathrm{H},{ }^{3} J_{\mathrm{HH}}=6.8 \mathrm{~Hz}, \mathrm{CH}\right.$ $\left.\left(\mathrm{CH}_{3}\right)_{2}\right), 1.28\left(\mathrm{~d}, 6 \mathrm{H},{ }^{3} \mathrm{~J}_{\mathrm{HH}}=6.8 \mathrm{~Hz}, \mathrm{CH}\left(\mathrm{CH}_{3}\right)_{2}\right), 1.18(\mathrm{~d}, 6 \mathrm{H}$, 
$\left.{ }^{3} J_{\mathrm{HH}}=6.8 \mathrm{~Hz}, \mathrm{CH}\left(\mathrm{CH}_{3}\right)_{2}\right), 1.12\left(\mathrm{~d}, 6 \mathrm{H},{ }^{3} J_{\mathrm{HH}}=6.8 \mathrm{~Hz}, \mathrm{CH}\right.$ $\left.\left(\mathrm{CH}_{3}\right)_{2}\right), 1.04\left(\mathrm{~d}, 3 \mathrm{H},{ }^{1} J_{\mathrm{PH}}=8.5 \mathrm{~Hz}, \mathrm{PCH}_{3}\right) .{ }^{13} \mathrm{C}\left\{{ }^{1} \mathrm{H}\right\} \mathrm{NMR}$ $\left(\mathrm{C}_{6} \mathrm{D}_{6}\right): \delta=148.9\left(\mathrm{~d},{ }^{3} J_{\mathrm{PC}}=2.1 \mathrm{~Hz}, o-\mathrm{C}\right), 148.4(\mathrm{~s}, o-\mathrm{C}), 138.4(\mathrm{~d}$, $\left.{ }^{2} J_{\mathrm{PC}}=12.6 \mathrm{~Hz}, \mathrm{i}-\mathrm{C}\right), 127.7$ (d, $\left.{ }^{4} J_{\mathrm{PC}}=1.7 \mathrm{~Hz}, m-\mathrm{C}\right), 124.9(\mathrm{~s}, p-\mathrm{C})$, $124.7\left(\mathrm{~d},{ }^{4} J_{\mathrm{PC}}=1.3 \mathrm{~Hz}, m-\mathrm{C}\right), 119.3\left(\mathrm{~d},{ }^{2} J_{\mathrm{PC}}=6.5 \mathrm{~Hz},=\mathrm{CH}\right)$, $29.1\left(\mathrm{~d},{ }^{4} J_{\mathrm{PC}}=6.1 \mathrm{~Hz}, \mathrm{CH}\left(\mathrm{CH}_{3}\right)_{2}\right), 28.7\left(\mathrm{~s}, \mathrm{CH}\left(\mathrm{CH}_{3}\right)_{2}\right), 25.9(\mathrm{~s}$, $\left.\mathrm{CH}_{3}\right), 25.4\left(\mathrm{~s}, \mathrm{CH}_{3}\right), 25.1\left(\mathrm{~s}, \mathrm{CH}_{3}\right), 24.2\left(\mathrm{~d},{ }^{5} J_{\mathrm{PC}}=2.7 \mathrm{~Hz}, \mathrm{CH}_{3}\right)$, $19.8\left(\mathrm{~d},{ }^{1} J_{\mathrm{PC}}=48.2 \mathrm{~Hz}, \mathrm{CH}_{3}\right)$.

\section{Crystal structure determinations}

Diffraction studies were carried out using a Bruker diffractometer equipped with a Kappa APEX II Duo CCD-detector and a KRYO-FLEX cooling device with Mo-K $\mathrm{K}_{\alpha}$ radiation $(\lambda=$ $0.71073 \AA$; complexes $\left.\left[\mathrm{PPh}_{4}\right][2], 3 \mathrm{a}, 5\right)$ or $\mathrm{Cu}-\mathrm{K}_{\alpha}$ radiation $(\lambda=$ $1.54178 \AA$ A; complexes 4, 6) at $T=100 \mathrm{~K}$. The structures were solved by direct methods (SHELXS-97 ${ }^{28}$ ) and refined with a full-matrix least-squares scheme on $F^{2}$ (SHELXL-2014 and SHELXL-97 ${ }^{28}$ ). Semi-empirical absorption corrections were applied for all structures. Non-hydrogen atoms were refined anisotropically, and $\mathrm{H}$ atoms with a riding model, on $F^{2}$. The hydrogen atom attached to the iron atom in $\mathbf{3 a}$ was located and refined freely using isotropic thermal displacement parameters. Details of the crystal structure determinations are listed in Table 1.

$\left[\mathrm{PPh}_{4}\right][2]$ is a racemic twin $(x=0.473(15))$, and an extinction correction was applied. Furthermore, one solvent molecule (THF) is disordered, and the high $U_{i j}$-values in another one indicate a slight disorder, which was not resolved. 4 shows high $U_{i j}$-values for the $\mathrm{Fe}(\mathrm{CO})_{3}$ moiety as well as for one 2,6-diisopropylphenyl substituent indicating a disorder. The disorder was resolved and modelled for the $\mathrm{Fe}(\mathrm{CO})_{3}$ moiety, the 2,6-diisopropylphenyl substituent and one iPr-group of the other 2,6-diisopropylphenyl substituent. Disordered C- and O-atoms in $\left[\mathrm{PPh}_{4}\right][2]$ and $\mathbf{4}$ were refined isotropically, and the Fe-atoms were refined anisotropically (see the cif-files for further details).

\section{Computational studies}

Computational studies were performed with the Gaussian $03^{29}$ suite of programs using def2-tzvp basis sets ${ }^{30}$ (obtained from the basis set exchange home page ${ }^{31,32}$ ) on model compounds $\mathbf{2}^{\prime},\left[\mathrm{Li}\left(\mathrm{OMe}_{2}\right)_{3}\right]\left[\mathbf{2}^{\prime}\right], \mathbf{3}^{\prime}$ and $\mathbf{5}^{\prime}$ featuring NMe instead of the larger NDipp substituents. Solvent effects were included by using a PCM model as implemented in the Gaussian package (SCRF = THF). Molecular structures were first energy optimized without symmetry constraints. Calculation of harmonic vibrational frequencies was performed in order to ensure that all stationary points located were of local minima on the energy hypersurface (in case of $\left[2^{\prime}\right]\left[\mathrm{Li}\left(\mathrm{OMe}_{2}\right)_{3}\right]$, the molecular structure had to be re-optimized using a smaller def2-svp basis set for the $\left[\mathrm{Li}\left(\mathrm{OMe}_{2}\right)_{3}\right]^{+}$cation, and the frequency calculation was performed at the same level. The structural features of both models showed no significant deviations). The NBO analysis ${ }^{33}$ was performed with the NBO 3.1 program as implemented in the Gaussian package. MOLDEN ${ }^{34}$ was used for the visualization of Kohn-Sham orbitals.

Table 1 Crystallographic data for complexes $\left[\mathrm{PPh}_{4}\right][2], 3 a, 4-6$

\begin{tabular}{|c|c|c|c|c|c|}
\hline & {$\left[\mathrm{PPh}_{4}\right][2]$} & $3 a$ & 4 & 5 & 6 \\
\hline CCDC & 1032393 & 1032390 & 1032394 & 1032391 & 1032392 \\
\hline Formula & $\mathrm{C}_{29} \mathrm{H}_{36} \mathrm{FeN}_{2} \mathrm{O}_{3} \mathrm{P}-\mathrm{C}_{24} \mathrm{H}_{20} \mathrm{P}-1.5 \mathrm{THF}$ & $\mathrm{C}_{29} \mathrm{H}_{37} \mathrm{FeN}_{2} \mathrm{O}_{3} \mathrm{P}$ & $\mathrm{C}_{47} \mathrm{H}_{51} \mathrm{FeN}_{2} \mathrm{O}_{3} \mathrm{PSn}$ & $\mathrm{C}_{54} \mathrm{H}_{72} \mathrm{FeN}_{4} \mathrm{O}_{2} \mathrm{P}_{2}$ & $\mathrm{C}_{31} \mathrm{H}_{39} \mathrm{FeN}_{2} \mathrm{O}_{4} \mathrm{P}$ \\
\hline Formula weight & 994.94 & 548.43 & 897.40 & 926.95 & 590.46 \\
\hline Crystal size (mm) & $0.28 \times 0.22 \times 0.04$ & $0.32 \times 0.22 \times 0.18$ & $0.15 \times 0.09 \times 0.06$ & $0.27 \times 0.18 \times 0.12$ & $0.14 \times 0.11 \times 0.03$ \\
\hline$T[\mathrm{~K}]$ & $100(2)$ & $100(2)$ & $100(2)$ & $100(2)$ & $100(2)$ \\
\hline Crystal system & Orthorhombic & Monoclinic & Triclinic & Monoclinic & Orthorhombic \\
\hline Space group & $\operatorname{Pna2}_{1}$ & $P 2_{1} / n$ & $P \overline{1}$ & $P 2_{1} / n$ & Pnma \\
\hline$a(\AA)$ & $19.0086(16)$ & $10.9098(8)$ & $11.5843(6)$ & $13.5063(5)$ & $19.7315(14)$ \\
\hline$b(\AA)$ & $12.8494(10)$ & $15.3843(11)$ & $12.2340(6)$ & $21.9821(8)$ & $20.5098(16)$ \\
\hline$c(\AA)$ & $43.849(3)$ & $17.7380(11)$ & $17.8887(11)$ & $18.0479(5)$ & $7.4442(6)$ \\
\hline$\alpha\left({ }^{\circ}\right)$ & 90 & 90 & $92.606(3)$ & 90 & 90 \\
\hline$\beta\left({ }^{\circ}\right)$ & 90 & $99.998(2)$ & $103.175(3)$ & $107.775(1)$ & 90 \\
\hline$\gamma\left({ }^{\circ}\right)$ & 90 & 90 & $116.117(2)$ & 90 & 90 \\
\hline$V\left(\AA^{3}\right)$ & $10710.2(14)$ & $2931.9(4)$ & $2185.4(2)$ & $5102.6(3)$ & $3012.6(4)$ \\
\hline Density $\left(\mathrm{Mg} \mathrm{m}^{-3}\right)$ & 1.234 & 1.242 & 1.364 & 1.207 & 1.302 \\
\hline$F(000)$ & 4224 & 1160 & 924 & 1984 & 1248 \\
\hline$Z$ & 8 & 4 & 2 & 4 & 4 \\
\hline Abs. coeff. $\mu\left(\mathrm{mm}^{-1}\right)$ & 0.390 & 0.599 & 7.870 & 0.401 & 4.814 \\
\hline Absorption correction & Semi-empirical & Semi-empirical & Semi-empirical & Semi-empirical & Semi-empirical \\
\hline Data collected & 56223 & 21309 & 39721 & 32673 & 16472 \\
\hline Unique data & $18565\left(R_{\text {int }}=0.100\right)$ & $6011\left(R_{\text {int }}=0.077\right)$ & $7394\left(R_{\mathrm{int}}=0.053\right)$ & $8997\left(R_{\mathrm{int}}=0.048\right)$ & $2677\left(R_{\text {int }}=0.038\right)$ \\
\hline Observed data with $I>2 \sigma(I)$ & 13658 & 3685 & 6119 & 6259 & 2441 \\
\hline Restraints & 179 & 1 & 277 & 0 & 0 \\
\hline Variables & 1231 & 329 & 464 & 568 & 198 \\
\hline$R_{1}(I>2 \sigma(I))$ & 0.060 & 0.047 & 0.040 & 0.038 & 0.029 \\
\hline $\mathrm{w} R_{2}$ & 0.118 & 0.097 & 0.092 & 0.080 & 0.081 \\
\hline GOF & 1.04 & 0.99 & 1.03 & 0.99 & 1.06 \\
\hline Max. diff. dens. $\left(\mathrm{e}^{\mathrm{A}}{ }^{-3}\right)$ & 0.715 & 0.440 & 0.825 & 0.285 & 0.396 \\
\hline Min. diff. dens. $\left(\mathrm{e}^{-3}\right)$ & -0.476 & -0.290 & -1.314 & -0.313 & -0.388 \\
\hline
\end{tabular}




\section{Acknowledgements}

Financial support by Deutsche Forschungsgemeinschaft (grant GU 415/15-1) is gratefully acknowledged.

\section{Notes and references}

1 Reviews: (a) A. H. Cowley and R. A. Kemp, Chem. Rev., 1985, 85, 367; (b) M. Sanchez, M. R. Mazières, L. Lamandé and R. Wolf, in Multiple Bonds and Low Coordination Chemistry in Phosphorus Chemistry, ed. M. Regitz and O. J. Scherer, Thieme, Stuttgart, 1990, 129ff; (c) D. Gudat, Coord. Chem. Rev., 1997, 163, 71; (d) H. Nakazawa, Adv. Organomet. Chem., 2004, 50, 107; (e) L. Rosenberg, Coord. Chem. Rev., 2012, 256, 606.

2 (a) M. B. Abrams, B. L. Scott and R. T. Baker, Organometallics, 2000, 19, 4944; (b) C. A. Caputo, M. C. Jennings, H. M. Tuononen and N. D. Jones, Organometallics, 2009, 28, 990.

3 L. Hutchins, E. Duesler and R. Paine, Organometallics, 1982, 1, 1254.

4 M. L. H. Green, J. Organomet. Chem., 1995, 200, 127.

5 S. Burck, J. Daniels, T. Gans-Eichler, D. Gudat, K. Nättinen and M. Nieger, Z. Anorg. Allg. Chem., 2005, 631, 1403.

6 B. Pan, Z. Xu, M. W. Bezpalko, B. M. Foxman and C. M. Thomas, Inorg. Chem., 2012, 51, 4170.

7 (a) D. Gudat, A. Haghverdi and M. Nieger, J. Organomet. Chem., 2001, 617, 383; (b) D. Förster, J. Nickolaus, M. Nieger, Z. Benkö, A. W. Ehlers and D. Gudat, Inorg. Chem., 2013, 52, 7699.

8 (a) L. D. Hutchins, R. T. Paine and C. F. Campagna, J. Am. Chem. Soc., 1980, 102, 4521; (b) L. D. Hutchins, H.-U. Reisacher, G. L. Wood, E. N. Duesler and R. T. Paine, J. Organomet. Chem., 1987, 335, 229; (c) C. A. Caputo, A. L. Brazeau, Z. Hynes, J. T. Price, H. M. Tuononen and N. D. Jones, Organometallics, 2009, 28, 5261.

9 (a) H.-U. Reisacher, E. N. Duesler and R. T. Paine, J. Organomet. Chem., 1998, 564, 13; (b) H.-U. Reisacher, E. N. Duesler and R. T. Paine, J. Organomet. Chem., 1997, 539, 37; (c) H.-U. Reisacher, W. F. McNamara, E. N. Duesler and R. T. Paine, Organometallics, 1997, 16, 449; (d) H.-U. Reisacher, E. N. Duesler and R. T. Paine, Chem. Ber., 1996, 129, 279; (e) W. E. McNamara, E. N. Duesler, R. T. Paine, J. V. Ortiz, P. Koelle and H. Nöth, Organometallics, 1986, 5, 380.

10 S. Magens and B. Plietker, J. Org. Chem., 2010, 75, 3715.

11 (a) A. H. Cowley, E. A. Kemp, E. A. V. Ebsworth, D. W. H. Rankin and M. D. Walkinshaw, J. Organomet. Chem., 1984, 265, C19; (b) H. Nakazawa, Y. Yamaguchi, K. Kawamura and K. Miyoshi, Organometallics, 1997, 16, 4626.

12 J.-J. Brunet, R. Chauvin, O. Diallo, B. Donnadieu, J. Jaffart and D. Neibecker, J. Organomet. Chem., 1998, 570, 195.
13 (a) H. B. Chin and R. Bau, J. Am. Chem. Soc., 1976, 98, 2434; (b) R. G. Teller, R. G. Finke, J. P. Collman, H. B. Chin and R. Bau, J. Am. Chem. Soc., 1977, 99, 1104.

14 L. M. Clarkson, W. Clegg, D. C. R. Hockless and N. C. Norman, Acta Crystallogr., Sect. C: Cryst. Struct. Commun., 1992, 48, 236.

15 For appropriate studies on $\left[\mathrm{HFe}(\mathrm{CO})_{4}\right]^{-}$and $[\mathrm{HFe}-$ $\left.(\mathrm{CO})_{3}\left(\mathrm{PR}_{3}\right)\right]^{-}$see: (a) M. Y. Darensbourg, H. J. Darensbourg and H. L. C. Barros, Inorg. Chem., 1978, 17, 297; (b) C. E. Ash, T. Delord, D. Simmons and M. Y. Darensbourg, Organometallics, 1986, 5, 17.

16 B. Zhou and J. M. Goicoechea, Chem. - Eur. J., 2010, 16, 11145. 17 (a) M. Zhou and L. Andrews, J. Chem. Phys., 1999, 110, 10370; (b) G. Wang, C. Chi, J. Cui, X. Xing and M. Zhou, J. Phys. Chem. A, 2012, 116, 2484.

18 Raman data: P. S. Braterman, J. Mol. Spectrosc., 1977, 65, 334.

19 J. E. Ellis and Y.-S. Chen, Organometallics, 1989, 8, 1350.

20 A. E. Reed, R. B. Weinstock and F. Weinhold, J. Chem. Phys., 1985, 83, 735.

21 J. E. M. N. Klein, B. Miehlich, M. S. Holzwarth, M. Bauer, M. Milek, M. M. Khusniyarov, G. Knizia, H.-J. Werner and B. Plietker, Angew. Chem., Int. Ed., 2014, 53, 1790.

22 J.-J. Brunet, R. Chauvin and D. Neibecker, Synth. Commun., 1997, 27, 1433.

23 (a) R. Mathieu, A.-M. Caminade, J.-P. Majoral, S. Attali and M. Banchez, Organometallics, 1986, 5, 1914; (b) R. Mathieu, A.-M. Caminade, J.-P. Majoral and J.-C. Daran, J. Am. Chem. Soc., 1986, 108, 8007; (c) A.-M. Caminade, J.-P. Majoral, M. Sanchez, R. Mathieu, S. Attali and A. Grand, Organometallics, 1987, 6, 1459; (d) H. Westermann, M. Nieger, E. Niecke, J.-P. Majoral, A.-M. Caminade and R. Mathieu, Organometallics, 1989, 8, 244.

24 For a first such complex see: J. P. Bezombes, P. B. Hitchcock, M. F. Lappert and J. E. Nycz, Dalton Trans., 2004, 499.

25 A. Poletti, A. Santucci and A. Foffani, J. Mol. Struct., 1969, 3, 311.

26 H. Nakazawa, Y. Yamaguchi, T. Mizuta, S. Ichimura and K. Miyoshi, Organometallics, 1995, 14, 4635.

27 W. A. Herrmann, K. Öfele and C. E. Zybill, in Synthetic Methods in Organometallic and Inorganic Chemistry, ed. W. A. Herrmann, Thieme, Stuttgart, 1997, vol. 7, $24 \mathrm{ff}$.

28 G. M. Sheldrick, Acta Crystallogr., Sect. A: Fundam. Crystallogr., 2008, 64, 112.

29 M. J. Frisch, G. W. Trucks, H. B. Schlegel, G. E. Scuseria, M. A. Robb, J. R. Cheeseman, J. A. Montgomery Jr., T. Vreven, K. N. Kudin, J. C. Burant, J. M. Millam, S. S. Iyengar, J. Tomasi, V. Barone, B. Mennucci, M. Cossi, G. Scalmani, N. Rega, G. A. Petersson, H. Nakatsuji, M. Hada, M. Ehara, K. Toyota, R. Fukuda, J. Hasegawa, M. Ishida, T. Nakajima, Y. Honda, O. Kitao, H. Nakai, M. Klene, X. Li, J. E. Knox, H. P. Hratchian, J. B. Cross, V. Bakken, C. Adamo, J. Jaramillo, R. Gomperts, R. E. Stratmann, O. Yazyev, A. J. Austin, R. Cammi, C. Pomelli, J. W. Ochterski, P. Y. Ayala, K. Morokuma, 
G. A. Voth, P. Salvador, J. J. Dannenberg, V. G. Zakrzewski, S. Dapprich, A. D. Daniels, M. C. Strain, O. Farkas, D. K. Malick, A. D. Rabuck, K. Raghavachari, J. B. Foresman, J. V. Ortiz, Q. Cui, A. G. Baboul, S. Clifford, J. Cioslowski, B. B. Stefanov, G. Liu, A. Liashenko, P. Piskorz, I. Komaromi, R. L. Martin, D. J. Fox, T. Keith, M. A. Al-Laham, C. Y. Peng, A. Nanayakkara, M. Challacombe, P. M. W. Gill, B. Johnson, W. Chen, M. W. Wong, C. Gonzalez and J. A. Pople, Gaussian 03, Revision E.01, Gaussian, Inc., Wallingford CT, 2004.
30 F. Weigend and R. Ahlrichs, Phys. Chem. Chem. Phys., 2005, 7, 3297.

31 D. Feller, J. Comput. Chem., 1996, 17, 1571.

32 K. L. Schuchardt, B. T. Didier, T. Elsethagen, L. Sun, V. Gurumoorthi, J. Chase, J. Li and T. L. Windus, J. Chem. Inf. Model., 2007, 47, 1045 (http://bse.pnl.gov/bse/portal).

33 E. D. Glendening, A. E. Reed, J. E. Carpenter and F. Weinhold, NBO Version 3.1.

34 G. Schaftenaar and J. H. Noordik, J. Comput. Aided Mol. Des., 2000, 14, 123. 